Cândido, L. F., Barros Neto, J. P. (2017). "Features, Roles and Processes of Performance Measurement in Lean Construction.” In: LC3 2017 Volume II - Proceedings of the 25th Annual Conference of the International Group for Lean Construction (IGLC), Walsh, K., Sacks, R., Brilakis, I. (eds.), Heraklion, Greece, pp. 243-250. DOI: https://doi.org/10.24928/2017/0290

\title{
FEATURES, ROLES AND PROCESSES OF PERFORMANCE MEASUREMENT IN LEAN CONSTRUCTION
}

\author{
Luis Felipe Cândido ${ }^{1}$ and José de Paula Barros Neto ${ }^{2}$
}

\begin{abstract}
The development of an adequate performance measurement system represents a challenge for all modern companies, including those applying Lean Construction (LC) principles. LC companies adopt a broader scope that focuses not only on traditional financial performance but also on process improvement and value creation. Thus, management should evolve to embrace different performance criteria and related indicators.

However, in spite of advances in other industries, in the construction sector, as well as LC, it is slow. Thus, this paper aims to analyse the performance measurement process in lean construction context through a multiple case study. This paper is expected to contribute to efforts undertaken by practitioners and academics because the framework and the gaps identified provide guidelines to what works and to what does not work when implementing performance measurement systems especially in LC projects.
\end{abstract}

Keywords: Lean construction, Performance Measurement, Performance Indicators, Metrics, Strategy.

\section{INTRODUCTION}

Since the spread of Toyota production principles, researchers have been trying to justify the change in production paradigm (from mass production to lean production). This occurs due of the apparent decrease of productivity in the early stages of lean implementation, from the point of view of traditional measurement systems, which are based on financial accounting (Åhlström 1998).

This has been increasing the interest of academics and professionals to the use of performance indicators in lean production (Chavez et al. 2013; Fullerton \& Wempe 2009). The main change in production paradigm shifted by Toyota principles was the focus on value creation for the customers, a fact which led the companies to change their strategies based on cost-leadership to strategies based on differentiation/customization. This change led a revolution in the field of Performance Measurement (Neely 1999).

Thus, the companies perceived the inappropriateness of its Performance Measurement Systems (PMS) that were based exclusively on financial accounts (Franco-Santos et al. 2012). In addition, qualitative aspects, such as customer satisfaction and quality assurance, have become fundamental in the evaluation of organizational performance (Kennerley \& Neely 2002). Such changes also occurred in the construction industry (Jin et al. 2013).

In the construction industry, the main initiatives to improve performance measurement are represented by benchmarking initiatives such as KPI and CII BM\&M (Costa et al. 2006). However, it is still not possible to check the contributions of those

Professor, Christus University Center (UNICHRISTU), Brazil, luisfcandido2015@gmail.com

Professor, Federal University of Ceará (UFC), Brazil, barrosneto@gercon.ufc.br 
initiatives in well-established management practices in the construction sector (Nudurupati et al. 2007; Deng et al. 2012; Korde et al. 2005). The PMS evolution is happening slowly, mainly when it is compared to other industries (Deng et al. 2012), demanding more studies in this research matter (Nudurupati et al. 2007; Deng et al. 2012; Korde et al. 2005).

It is necessary to come up with more comprehensive and applicable measurement systems (Yang et al. 2010; Kueng et al. 2001). Is also necessary to create conditions to enable the correct use of PMS already deployed in the companies (Taticchi et al. 2010). In the lean construction context, studies suggest that this question remains open ( $\mathrm{Li}$ et al. 2015; España et al. 2012; Alarcón et al. 2014).

Thus, this paper aims to analyse the performance measurement process in the lean construction context. Unlike most research in this matter that is focused only on performance indicators, this study is focused on the main characteristics, roles, processes to carry out an appropriate performance measurement. To accomplish this, a multiple case study was carried out with three construction companies from Fortaleza, a city northeast of Brazil, that applies lean construction.

\section{PERFORMANCE MEASUREMENT SYSTEM AND LEAN CONSTRUCTION}

Several structures to design and implement a performance measurement system are found in the literature. These models were created in different economic sectors and encompass a range of disciplines such as accounting, strategy, human resources, operations and production management, marketing, organizational behavior and strategic management (Neely 1999; Franco-Santos et al. 2012).

Thus, performance measurement is a multidisciplinary topic and there is still not a coherent structure for performance measurement (Choong 2013a), i.e, a PMS suitable for different environments. It is difficult to understand the meaning of 'performance' (Micheli \& Mari 2013), its attributes (Choong 2013b) and its structure to cover the role of performance measurement as a System (Toni \& Tonchia 2001). The process of measuring the performance is not clearly defined (Kueng et al. 2001).

Frequently, this lack of understanding leads to PMS to work as a simple control tool (Sink \& Tuttle 1993), instead of a cyclical and holistic management process (Lebas 1995). It seems clear that performance measurement plays a control role in the construction industry and does not drive continuous improvement due to emphasis on financial outcomes. A well-stablished criticism to this narrow approach has been mentioned by a number of authors (Bassioni et al. 2004; Nudurupati et al. 2011; Horstman \& Witteveen 2013).

This occurs due of the difficulty defining what successful project is in such a complex sector as construction, characterized by: the fragmented processes in the project (Horstman \& Witteveen 2013), the one-of-a-kind nature of a project with temporary location and temporary construction (Koskela 1992) and the existence of many stakeholders that follow different business practices with different objectives (WegeliusLehtonen 2001).

The status quo of PM becomes critical in lean construction. The performance of lean projects cannot be assessed through traditional measures (Horman \& Kenley 1996). Projects under lean construction principles aim to maximize value, minimize waste, reduce cycle times (Ballard et al. 2001), provide production stability and improve construction 
flow (Sacks et al. 2017), achieve continuous improvement and show respect for people (Korb 2016), among others things.

The performance measurement in lean construction projects should be grounded on physical and qualitative aspects of production progress and not only on financial outcomes (Cândido et al. 2014) which demonstrates the complexity of the performance measurement in lean construction (España et al. 2012).

To improve on understanding on performance measurement, Franco-Santos et al. (2007) suggested the following components as essential for an adequate PMS:

- Features: (i) to have a performance measurement; (ii) to support infrastructure;

- Roles: (i) to measure performance; (ii) strategy management; (iii) communication; (iv) to influence behaviour; (v) learning and improvement;

- Processes: (i) selection and design measures; (ii) data collection and manipulation; (iii) information management; (iv) performance evaluation and rewards; (v) system review;

Thus, to contribute to lean, a Performance Measurement System should provide continuous improvement. It should increase transparency and manage accountability (España et al. 2012). It should be a driving factor to the team's growth, to ensure respect for people, encompassing motivation and self-determination for both the individual and the collective staff.

Table 1 summarizes the PMS Roles and its driving factor for lean.

Table 1: PMS - Roles and its driving factor for lean

\begin{tabular}{|c|c|c|}
\hline Roles of PMS & Definition (Franco-Santos et al. 2007) & Driving factor for lean \\
\hline $\begin{array}{l}\text { Measure } \\
\text { performance }\end{array}$ & $\begin{array}{l}\text { This category encompasses the role of monitor } \\
\text { progress and measurement performance/evaluate } \\
\text { performance }\end{array}$ & $\begin{array}{l}\text { It allows value generation, } \\
\text { minimize waste, reduce cycle } \\
\text { times }\end{array}$ \\
\hline $\begin{array}{l}\text { Strategy } \\
\text { management }\end{array}$ & $\begin{array}{l}\text { This category comprises the roles of planning, } \\
\text { strategy, formulation, strategy } \\
\text { implementation/execution, and focus } \\
\text { attention/provide alignment }\end{array}$ & $\begin{array}{l}\text { Allows a maintenance } \\
\text { strategy and focus on lean } \\
\text { construction principles over } \\
\text { time }\end{array}$ \\
\hline Communication & $\begin{array}{l}\text { Comprises the roles of internal and external } \\
\text { communication, benchmarking and compliance } \\
\text { with regulations }\end{array}$ & $\begin{array}{l}\text { Information flow is a critical } \\
\text { issue to lean construction. } \\
\text { These roles should allow for } \\
\text { increased transparency and } \\
\text { accountability management }\end{array}$ \\
\hline $\begin{array}{l}\text { Influence } \\
\text { behavior }\end{array}$ & $\begin{array}{l}\text { It encompasses the roles of rewarding or } \\
\text { compensation behavior, managing relationships } \\
\text { and control }\end{array}$ & $\begin{array}{l}\text { It allows the respect for } \\
\text { people, motivation and self- } \\
\text { determination }\end{array}$ \\
\hline $\begin{array}{l}\text { Learning and } \\
\text { improvement }\end{array}$ & $\begin{array}{l}\text { It comprises the roles of feedback, double-loop } \\
\text { learning and performance improvement }\end{array}$ & $\begin{array}{l}\text { It allows the continuous } \\
\text { improvement, standardization }\end{array}$ \\
\hline
\end{tabular}

Thus, in this paper, the main features, roles and processes of PMS are analysed to check its capacity to facilitate a lean behaviour and to check its ability to promote lean construction.

\section{METHOD}

This study represents a multiple case study (Yin 2010) of three building companies. These companies have been operating for more than 25 years, working in the real estate market and applying lean construction for more than 10 years. 
Seven interviews were carried out, with 6 participants: 3 technical directors, 1 technical manager, 1 technical coordinator and 1 quality coordinator. Besides the interviews, documents were collected to support interviews claims.

The case study was structured to analyse the main features, roles and process according to Cândido et al. (2016) (Table 2).

Table 2: Example of audit criteria protocol ${ }^{3}$

\begin{tabular}{ll}
\hline Processes & Criteria \\
\hline & $\begin{array}{l}\text { Does the model present a procedure or provide guidelines to management and } \\
\text { information interpretation, connecting them to the decision-making process through } \\
\text { the operation of information transference mechanisms (discussion, debates, } \\
\text { publications, selective diffusion of information, others, or using ICTs)? }\end{array}$ \\
Information & - It does not provide any guideline. \\
management & $\begin{array}{l}\text { 1 - It provides guidelines to assure information reaches the interested ones and is } \\
\text { available to make decisions. } \\
\\
\text { 2 - It provides guidelines to assure the integrity and consistency of measurement } \\
\text { results, as well as the way they should be used (which information transference } \\
\text { mechanisms are supposed to be used?). }\end{array}$ \\
\hline
\end{tabular}

Thus, three points are attributed: (1) importance degree and (2) use degree - both in manager's point of view; (3) audit degree - in the researchers' point of view.

\section{RESULTS}

Table 3 shows the PMS evaluation results.

Table 2: Companies' self-assessment and audit for features, roles and processes

\begin{tabular}{|c|c|c|c|c|c|c|c|c|c|}
\hline \multirow{2}{*}{$\begin{array}{l}\text { Features, Roles and Processes to } \\
\text { Performance Measurement }\end{array}$} & \multicolumn{3}{|c|}{ Alpha Company } & \multicolumn{3}{|c|}{ Beta Company } & \multicolumn{3}{|c|}{ S Company } \\
\hline & $(1)$ & $(2)$ & (3) & $(1)$ & (2) & (3) & $(1)$ & $(2)$ & (3) \\
\hline A. Features & $100 \%$ & $85 \%$ & $75 \%$ & $93 \%$ & $73 \%$ & $75 \%$ & $90 \%$ & $60 \%$ & $75 \%$ \\
\hline a. Performance measures & $100 \%$ & $100 \%$ & $100 \%$ & $100 \%$ & $80 \%$ & $100 \%$ & $100 \%$ & $60 \%$ & $100 \%$ \\
\hline b. Supporting infrastructure & $100 \%$ & $70 \%$ & $50 \%$ & $87 \%$ & $67 \%$ & $50 \%$ & $80 \%$ & $60 \%$ & $50 \%$ \\
\hline B. Roles & $100 \%$ & $86 \%$ & $70 \%$ & $93 \%$ & $69 \%$ & $60 \%$ & $76 \%$ & $68 \%$ & $60 \%$ \\
\hline a. Measure Performance & $100 \%$ & $100 \%$ & $50 \%$ & $100 \%$ & $87 \%$ & $50 \%$ & $80 \%$ & $80 \%$ & $50 \%$ \\
\hline b. Strategy Management & $100 \%$ & $80 \%$ & $100 \%$ & $93 \%$ & $73 \%$ & $100 \%$ & $80 \%$ & $80 \%$ & $100 \%$ \\
\hline c. Communication & $100 \%$ & $80 \%$ & $50 \%$ & $87 \%$ & $73 \%$ & $50 \%$ & $100 \%$ & $80 \%$ & $100 \%$ \\
\hline d. Influence Behavior & $100 \%$ & $80 \%$ & $100 \%$ & $87 \%$ & $53 \%$ & $50 \%$ & $60 \%$ & $40 \%$ & $0 \%$ \\
\hline e. Learning and Improvement & $100 \%$ & $90 \%$ & $50 \%$ & $100 \%$ & $60 \%$ & $50 \%$ & $60 \%$ & $60 \%$ & $50 \%$ \\
\hline C. Processes & $98 \%$ & $90 \%$ & $40 \%$ & $92 \%$ & $73 \%$ & $70 \%$ & $84 \%$ & $60 \%$ & $50 \%$ \\
\hline g. Selection and design measures & $100 \%$ & $100 \%$ & $50 \%$ & $100 \%$ & $93 \%$ & $100 \%$ & $100 \%$ & $80 \%$ & $100 \%$ \\
\hline h. Data collection and manipulation & $100 \%$ & $90 \%$ & $0 \%$ & $100 \%$ & $80 \%$ & $100 \%$ & $100 \%$ & $80 \%$ & $50 \%$ \\
\hline i. Information management & $100 \%$ & $80 \%$ & $50 \%$ & $80 \%$ & $60 \%$ & $50 \%$ & $100 \%$ & $80 \%$ & $50 \%$ \\
\hline j. Performance evaluation and rewards & $90 \%$ & $90 \%$ & $50 \%$ & $93 \%$ & $80 \%$ & $50 \%$ & $60 \%$ & $40 \%$ & $0 \%$ \\
\hline k. System review & $100 \%$ & $90 \%$ & $50 \%$ & $87 \%$ & $53 \%$ & $0 \%$ & $60 \%$ & $20 \%$ & $50 \%$ \\
\hline
\end{tabular}

Legend: (1) importance degree; (2) use degree; (3) audit scored

\footnotetext{
${ }^{3}$ see complete table at https://goo.gl/fu2Myt
} 


\subsection{Analysis of the Companies' PMS characteristics}

Regarding characteristics, a Measurement System must have performance indicators aligned with the companies' strategies, a fact which was not observed explicitly. For improvements, there are models that allow quick visualization of those pieces of information, for example, the matrix proposed by Kagioglou, Cooper and Aquad (2001), Kaplan and Norton $(1992,1996)$.

The infrastructure reached a low degree at the evaluation on the company manager's view and on the auditing perspective as well. This is also verified at the literature (Cândido et al. 2016; Kennerley \& Neely 2002).

Regarding the indicators used by the companies, Alpha Company has a Lean Audit, which was presented by Valente et al. (2012). The other performance indicators are traditional and widely spread as PPC, PCR, Cost Variance, ROI, among others. But in general they are focused on cost control and financial outcomes.

\subsection{Analysis of the Companies' PMS roles}

Regarding roles, Alpha PMS Company measures and evaluates performance. Beta Company's primary goal is to measure performance and to provide learning and improvements. Finally, for the S Company, the most important goal is to communicate results, even though they showed not to have expertise in its use.

All companies' PMS do not have well-established processes to follow the decisions progress made from the performance evaluation, which is an opportunity for improvement.

For the companies, the worst role was to influence behaviour (average of $58 \%$ for the companies). This result corroborates with the literature (Cândido et al. 2016). This is critical, since the implementation of a culture of improvement arising from PMS is of extreme importance (Kennerley \& Neely 2002; Sink \& Tuttle 1993). Like PMS, one of the basic PMS elements is the people (Kueng et al. 2001). Without this role, the focus on indicator (means to check the performance) becomes greater than the value generation (the goal) (Sink \& Tuttle 1993). This is also true in Lean Construction context.

\subsection{Process Analysis}

Regarding selection and definition of indicators, only Beta and S companies own indicator handbooks. The formalization of data collection and processing is the recommended to improving the Alpha Company's PMS. Process formalization is an important characteristic of a measurement system (Toni \& Tonchia 2001). Training about indicators may minimize misunderstandings and formalize knowledge about the company (Flapper et al. 2006).

Regarding data collection and processing, Alpha Company PMS neither offers guidelines about the data source to be used, no information about which tool will be used for the procedure. This item can be enhanced by using the proposed indicator handbook and training the ones responsible for collection. When it is not well established, data collection may make PMS unproductive and expensive for the company.

For information management it was possible to see good practices found in lean construction. Beta Company uses visual devices to spread information about the construction site. Alpha Company measures partners' performance (suppliers) and involves them in the discussions at meetings.

Towards the process of performance evaluation and rewards, Alpha Company selfassessed with $90 \%$. It does not have a formalized process for evaluation and awarding, although there is an award for each work phase. This award goes according to the financial performance of each finished stage. 
In Beta Company, at the organization level, every three months there is a meeting named "Accountability Meeting". Each area manager exhibits the results for their respective director. These results are consolidated into a single annual indicator for each area. Having meetings to discuss indicators is a positive point, because the need to use indicator should not only offer a communication of results to the superior hierarchic levels. As Sink and Tuttle (1993) and Kennerley and Neely (2002) point out, the creation of a measurement culture is an important step to implement any performance measurement system.

An improvement opportunity for Alpha and Beta Companies is to formalize the awarding process by matching the rewards to goals. Whereas, for the S Company, a rewarding culture must be created to encourage improvements, obviously this process must be well formalized and based on goals.

Regarding continuous improvement of the system there is no established process of revising its indicators neither revising the system consistency. The revision, in general, is only focused on goals evaluation. This practice is below expectations, since the whole system utility, efficiency and consistency must be revised so that the system does not become obsolete and unproductive.

\section{CONCLUSIONS}

This paper aims to analyse the performance measurement process in a lean construction context focused on the main characteristics, roles and processes to carry out an adequate performance measurement.

Despite of the limitations of a case study, it is possible that the PMS (performance measurement system) is too fragile to promote Lean. It is worth noticing that the design and selection of measures were not derived from Lean Construction principles. LC companies should adopt a broader scope that focuses not only on traditional financial performance but also on process improvement and value creation. Thus, management should evolve to embrace different performance criteria and related indicators.

\section{REFERENCES}

Åhlström, P., 1998. Sequences in the implementation of lean production. European Management Journal, 16(3), pp.327-334.

Alarcón, L.F., Salvatierra, J.L. \& Letelier, J.A. 2014, 'Using Last Planner Indicators to Identify Early Signs of Project Performance' In: Kalsaas, B.T., Koskela, L. \& Saurin, T.A., 22nd Annual Conference of the International Group for Lean Construction. Oslo, Norway, 25-27 Jun 2014. pp 547-558

Ballard, G. et al., 2001. Production System Design in Construction. Annual Conference of the International Group for Lean Construction, 9, pp.1-15.

Bassioni, H.A., Price, A.D.F. \& Hassan, T.M., 2004. Performance Measurement in Construction. Journal of Management in Engineering, 20(2), pp.42-50.

Cândido, L.F., Heineck, L.F.M. \& Neto, J.D.P.B. 2014, 'Critical Analysis on Earned Value Management (EVM) Technique in Building Construction ' In: Kalsaas, B.T., Koskela, L. \& Saurin, T.A., 22nd Annual Conference of the International Group for Lean Construction. Oslo, Norway, 25-27 Jun 2014. pp. 159-170

Cândido, L.F., Lima, S.H. de O. \& Barros Neto, J. de P., 2016. Análise de Sistemas de Medição de Desempenho na Indústria da Construção. Ambiente Construído, 16(2), pp.189-208. 
Chavez, R. et al., 2013. Internal lean practices and operational performance: The contingency perspective of industry clockspeed. International Journal of Operations \& Production Management, 33(5), pp.562-588.

Choong, K.K., 2013a. Has this large number of performance measurement publications contributed to its better understanding? A systematic review for research and applications. International Journal of Production Research, 52(14), pp.4174-4197.

Choong, K.K., 2013b. Understanding the features of performance measurement system: a literature review. Measuring Business Excellence, 17(4), pp.102-121.

Costa, D.B. et al., 2006. Benchmarking Initiatives in the Construction Industry: Lessons Learned and Improvement Opportunities. Journal of Management in Engineering, 22(4), pp.158-167.

Deng, F., Smyth, H. \& Anvuur, A., 2012. A critical review of PMS in construction: Towards a research agenda. In: Annual ARCOM Conference, 28(September), pp.807-816.

España, F., Tsao, C.C. \& Hauser, M. 2012, 'Driving Continuous Improvement by Developing and Leveraging Lean Key Performance Indicators' In: Tommelein, I.D. \& Pasquire, C.L., 20th Annual Conference of the International Group for Lean Construction. San Diego, USA, 18-20 Jul 2012.

Flapper, S.D.F., Fortuin, L. \& Stoop, P.P.M., 2006. Towards consistent perfromance management system. International Journal of Operations \& Production Management, 16(7), pp.27-37.

Franco-Santos, M. et al., 2007. Towards a definition of a business performance measurement system. International Journal of Operations \& Production Management, 27(8), pp.784-801.

Franco-Santos, M., Lucianetti, L. \& Bourne, M., 2012. Contemporary performance measurement systems: A review of their consequences and a framework for research. Management Accounting Research, 23(2), pp.79-119.

Fullerton, R.R. \& Wempe, W.F., 2009. Lean manufacturing, non-financial performance measures, and financial performance. International Journal of Operations \& Production Management, 29(3), pp.214-240.

Horman, M. \& Kenley, R. 1996, 'The Application of Lean Production to Project Management ' In: 4th Annual Conference of the International Group for Lean Construction. Birmingham, UK, 1-8.

Horstman, A. \& Witteveen, W., 2013. Performance Indicators in the Best Value Approach. Advanced of Performance Information \& Value, 5(2), pp.59-78.

Jin, Z. et al., 2013. Practical Framework for Measuring Performance of International Construction Firms. Journal of Construction Engineering and Management, 139(9), pp.1154-1167.

Kagioglou, M., Cooper, R. \& Aquad, G., 2001. Performance management in construction: a conceptual framework. Construction Management and Economics, 19, pp.85-95.

Kaplan, R.S. \& Norton, D.P., 1992. The Balanced Scorecard - Measures that Drive Performance. Havard Business Review, 70(1), pp.70-79.

Kaplan, R.S. \& Norton, D.P., 1996. Using the Balanced Scorecard as a Strategic Management System. Harvard Business Review, 74(1), pp.75-85.

Kennerley, M. \& Neely, A., 2002. A framework of the factors affecting the evolution of performance measurement systems. International Journal of Operations \& Production Management, 22(11), pp.1222-1245.

Korb, S. 2016, '"Respect for People” and Lean Construction: Has the Boat Been Missed?' In: 24th Annual Conference of the International Group for Lean Construction. Boston, USA, 20-22 Jul 2016. 
Korde, T., Li, M. \& Russell, A.D., 2005. State-of-the-Art review of Construction Performance Models and Factors. In: Construction Research Congress 2005. San Diego, E. U. A: ASCE, pp. 1-14.

Koskela, L., 1992. Application of the new production philosophy to construction. Stanford: Techniccal Repport 72. Center for Integrated Facility Engineering. Department of Civil Engineering. Stanford Univeristy.

Kueng, P., Andreas, M. \& Wttstein, T., 2001. Performance Measurement Systems Must Be Engineered. Communications of the Association for Information Systems, 7(3), pp.127.

Lebas, M.J., 1995. Performance measurement and performance management. International Journal of Production Economics, 41(1), pp.23-35.

Li, S., Wu, X., Hu, S. \& Hu, B. 2015, 'Performance Evaluation of Lean Construction Projects Based on Balanced Scorecard' In: Seppänen, O., González, V.A. \& Arroyo, P., 23rd Annual Conference of the International Group for Lean Construction. Perth, Australia, 29-31 Jul 2015. pp 753-762

Micheli, P. \& Mari, L., 2013. The theory and practice of performance measurement. Management Accounting Research, 25(2), pp.147-156.

Neely, A., 1999. The performance measurement revolution: why now and what next? International Journal of Operations \& Production Management, 19(2), pp.205-228.

Nudurupati, S., Arshad, T. \& Turner, T., 2007. Performance measurement in the construction industry: An action case investigating manufacturing methodologies. Computers in Industry, 58(7), pp.667-676.

Nudurupati, S.S. et al., 2011. State of the art literature review on performance measurement. Computers \& Industrial Engineering, 60(2), pp.279-290.

Sacks, R. et al., 2017. Construction flow index: a metric of production flow quality in construction. Construction Management and Economics, 6193(February), pp.1-19.

Sink, D.S. \& Tuttle, T.C., 1993. Planejamento e medição para performance, Rio de Janeiro, RJ: Qualitymark.

Taticchi, P., Tonelli, F. \& Cagnazzo, L., 2010. Performance measurement and management: a literature review and a research agenda. Measuring Business Excellence, 14(1), pp.418.

Toni, A. de \& Tonchia, S., 2001. Performance Measurement Systems: models, characteristics and measures. International Jounal of Operations \& Production Management, 21(1/2), pp.46-70.

Wegelius-Lehtonen, T., 2001. Performance measurement in construction logistics. International Journal of Production Economics, 69(1), pp.107-116.

Yang, H. et al., 2010. A critical review of performance measurement in construction. Journal of Facilities Management, 8(4), pp.269-284.

Yin, R.K., 2010. Estudo de caso: planejamento e métodos 4th ed., Porto Alegre: Bookman. 